\title{
Caesalpinia echinata Lam. - BRAZILWOOD: THERMAL BEHAVIOR, STRUCTURAL CHARACTERISTICS, AND RESISTANCE TO BIODETERIORATION IN STATIC SYSTEMS ${ }^{1}$
}

\author{
Ana Paula Pinto Pinheiro ${ }^{2}$ and José Roberto Moraes d'Almeida ${ }^{3 *}$
}

\footnotetext{
${ }^{1}$ Received on 18.02.2014 accepted for publication on 25.10.2016.

${ }^{2}$ Pontifícia Universidade Católica do Rio de Janeiro, Programa de Pós-Graduação em Engenharia de Materiais, Rio de Janeiro, RJ - Brasil. E-mail: <anapppinheiro@yahoo.com.br>.

${ }^{3}$ Pontifícia Universidade Católica do Rio de Janeiro, Departamento de Engenharia Química e de Materiais, Rio de Janeiro, RJ - Brasil. E-mail: <dalmeida@puc-rio.br>.

*Corresponding author.
}

\begin{abstract}
Wood is the best-known biological material used as a raw material since the dawn of mankind until present days. As a natural and renewable composite, its lifetime is limited by the degradation of its basic elements. This degradation can be caused by chemical reactions or by biological agents capable of accelerating the process of deterioration. In this work, the wear, thermal, and micro-structural characteristics, as also the bio-degradation behavior in static systems, of the wood species Brazilwood (Caesalpinia echinata) were studied under laboratory conditions in order to use these woods in design. The results show that Brazilwood has a good visual performance after abrasion test, since it has not shown any representative roughness increase. In addition, Brazilwood has high level of crystallinity of, approximately, $68 \%$ and was almost insensitive to fungi attack, forming only $5.3 \times 10^{3} \mathrm{CFU} / \mathrm{mL}$. Besides, its texture did not change due to exposure to water or sweat.
\end{abstract}

Keywords: Wood surface texture; Wood wear; Brazilwood (Caesalpinia echinata).

\section{Caesalpinia echinata LAm. - PAU-BRASIL: COMPORTAMENTO TÉRMICO, ASPECTOS ESTRUTURAIS E RESISTENCIA A BIODETERIORAÇÃO EM SISTEMAS ESTÁTICOS}

\begin{abstract}
RESUMO-A madeira éo material biológico mais conhecido e utilizado como matéria-prima desde os primórdios da humanidade até os dias atuais. Como um compósito natural e renovável, seu tempo de vida útil é limitado pela degradação de seus elementos básicos. Essa degradação pode ser ocasionada por reações químicas ou por agentes biológicos capazes de acelerar o processo de deterioração. Nesse contexto, esse trabalho teve como objetivo avaliar, sob condições laboratoriais, características de abrasão, térmica, microestruturais e de biodeterioração em sistemas estáticos da espécie de madeira Pau-Brasil (Caesalpinia echinata), com a finalidade de avaliar sua utilização em projetos de design. Os resultados mostram que o pau-brasil apresentou bom desempenho visual após ensaio de abrasão, pois não mostrou aumento representativo da rugosidade. Além disso o pau-brasil tem alto índice de cristalinidade de, aproximadamente, 68\% e foi pouco sensivel a ataques de fungos, com a formação de apenas 5,3 x $10^{3} \mathrm{UFC} / \mathrm{mL}$. Não houve também qualquer variação de textura causada por água ou suor.
\end{abstract}

Palavras-chave: Madeira textura superficial; Madeira abrasão; Pau-Brasil (Caesalpinia echinata). 


\section{INTRODUCTION}

Noble wood that gave its name to the country, Brazilwood is a rare tree in the Brazilian flora. It is currently on the list of IBAMA among species threatened with extinction, but as threatened as several others that populate the Atlantic Forest. With the scientific name Caesalpinia echinata Lam., Brazilwood belongs to the family Caesalpiniaceae (AGUIAR, et al, 2007); of the genus Caesalpinia in homage to the botanist Andrea Caesalpinio. From botanical synonymy Guillandina echinata (Lam.) Spreng., it is also called by several popular names of as Pernambuco wood, Rosewood and Ibirapitanga, among others (LORENZI, 2008).

The exploration of Brazilwood may have been the first economic activity undertaken by the Portuguese in the Brazilian territory and until 1875 its wood was intensively used for the extraction of brazilin, which had the purpose of dyeing fabrics and making inks (LORENZI, 2008), besides lacquer pigments for paints (MORESI, 2005).

Currently, its wood is used for making bows for stringed instruments (LONGHI, 2005) and its exploitation is restricted because it is an endangered species. Furniture and other old pieces of Brazilwood may, however, be reused if the properties of the material were not affected during the time of use. In this context, this work has the objective of evaluating possible texture changes that Brazilwood pieces may present due to mechanical friction or contact with external agents, such as moisture and also sweat and fungi. The evaluation of texture variations is an important, and sometimes decisive, factor for the use of a given material in design projects either furniture or even for jewelry (PINHEIRO, 2013).

\section{MATERIALS AND METHODS}

\subsection{Materials}

The samples of Brazilwood were obtained from the reuse of old furniture. Test specimens were machined in the form of cylindrical billets, $16 \mathrm{~mm}$ in diameter and $20 \mathrm{~mm}$ in length, and in the form of a fine powder, without concern for particle size. Figure 1 shows the flowchart of the experimental procedure using both types of specimens.

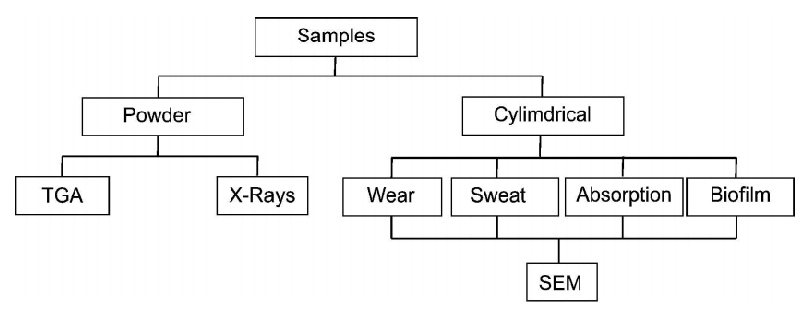

Figure 1 - Flow chart of the experimental procedures. Figura 1 - Fluxograma do procedimento experimental.

\subsection{Experimental methods}

The thermogravimetric analysis was performed in a sample with a mass of $8 \mathrm{mg}$ in a Perkin-Elmer thermal analyzer, Pyris 1 model, between $27^{\circ} \mathrm{C}$ and $800^{\circ} \mathrm{C}$, under nitrogen atmosphere, with a flow rate of $20 \mathrm{~mL} / \mathrm{min}$ and a heating rate of $10^{\circ} \mathrm{C} / \mathrm{min}$.

The X-ray diffraction test was performed using a Siemens D5000 diffractometer, with a $2 \theta$ scan between $5^{\circ}$ and $70^{\circ}$, with a step of $0.02^{\circ}$, a voltage of $40 \mathrm{kV}$, a current of $35 \mathrm{~mA}$ and a copper tube $(\lambda=1,5406 \AA)$. From this study, the crystallinity index (CI) of Brazilwood was calculated using the following equation (RONG, et al, 2001):

$$
I C(\%)=\frac{I_{002}-I_{a m}}{I_{002}} \cdot 100
$$

where, $I_{002}$ is the intensity of the (002) plane of natural cellulose at $2 \theta=23^{\circ}$ and $I_{a m}$ is the reflection intensity of the amorphous material at $2 \theta=18^{\circ}$.

The abrasion tests were carried out following the recommendations of DIN 53516 standard. The equipment used consists of a rotating cylinder, covered with a silicon carbide sandpaper (\# 60), and a sample holder, which rotates on its own axis and travels along the cylinder's length. Thus, the sample is rotated as it advances over the cylinder. The combined action of these movements produces a 40 meter path for the sample. The axial force exerted by the sample holder, which ensures permanent contact of the sample with the rotating cylinder, was kept constant and equal to 9.81 N. Five test specimens were used in this test and each specimen was measured with a caliper rule, with an accuracy of $\pm 0.05 \mathrm{~mm}$ and weighed within $\pm 0.0001 \mathrm{~g}$, before and after the abrasion test. The wear rate was calculated by the expression (FRIEDRICH, 1986): 


$$
W_{S}=\frac{\Delta m}{F_{N} \cdot L \cdot \rho}
$$

where $\Delta m$ is the loss of mass caused by wear, $F_{N}$ is the normal force exerted on the sample, $\mathrm{L}$ is the slip distance and $\rho$ is the specific mass of the material.

Water absorption and sweat exposure tests were performed in a similar manner. In these tests 3 specimens were immersed in $800 \mathrm{~mL}$ of distilled water or $200 \mathrm{~mL}$ of artificial sweat solution and were kept in a controlled temperature environment $\left(\mathrm{T}=23 \pm 2{ }^{\circ} \mathrm{C}\right)$. The artificial sweat solution was prepared according to ISO 3160 2, namely: $20 \mathrm{~g} / \mathrm{L}$ of sodium chloride, $17.5 \mathrm{~g} / \mathrm{L}$ of ammonium chloride, $5 \mathrm{~g} / \mathrm{L}$ of acetic acid, $15 \mathrm{~g} / \mathrm{L}$ of lactic acid, with $\mathrm{pH}$ adjusted to 4.7 by sodium hydroxide. These tests were performed for 3 months. In the absorption test the weight gain due to water absorption was measured periodically. For the sweat exposure test the samples were weighed only before and after the test. In both tests weighing was carried out with an accuracy of $\pm 0.0001 \mathrm{~g}$.

The biodeterioration test was carried out to evaluate the contribution of microorganisms in the deterioration process of Brazilwood, with the quantification of the filamentous fungi present in the formed biofilms. For this, the specimens were individually placed in an open Schott flask, with $20 \mathrm{~mL}$ of the Sabouraud broth, which is a culture medium specific for the growth of this microbial group. The samples were left at room temperature for contamination and growth of fungi in the air, for an approximate period of 15 to 20 days. After this period, the biofilm was scraped and $9.0 \mathrm{~mL}$ of saline solution was added to obtain a cell suspension. The technique chosen was the spread-plate technique (surface technique for counting colony forming units - CFUs). Approximately 15 to $20 \mathrm{~mL}$ of the Sabouraud agar was poured into Petri dishes and allowed to harden. Subsequently, the material was plated through the successive dilution method (APHA, 2005). After incubation in a bacteriological oven for 5 days at a temperature of $30^{\circ} \mathrm{C} \pm 2^{\circ} \mathrm{C}$, the cells or small clusters grew in isolation, giving rise to the CFUs.

The surfaces of the samples subjected to abrasion and exposed to sweat were analyzed by optical microscopy, for roughness evaluation, and by scanning electron microscopy (SEM), to evaluate the type of predominant abrasive wear mechanism. For the SEM analysis, the samples had to be pre-metallized with a gold conductive layer. These analyzes were performed with secondary electrons and electron beam acceleration between $10-15 \mathrm{kV}$.

The roughness evaluation was performed using an Imager M2m - Zeiss optical microscope, which allows to control the $\mathrm{x}-\mathrm{y}-\mathrm{z}$ motions of the sample displacement, so that $3 \mathrm{D}$ surface topography representations can be obtained. From the acquired images the arithmetic (RA) and quadratic (RQ) roughness were determined, using the $5 \mathrm{x}$ magnification lens. The roughness is calculated by the software of the equipment, having as parameter the RMS roughness (the root mean square average of the profile height), that is calculated as the standard deviation of the heights of the image pixels (MENEZES, 1998).

The samples submitted to the biodeterioration test were also analyzed by SEM to verify if any type of microstructural modification caused by fungus action occurred.

\section{RESULTS}

The result of the thermogravimetric analysis is shown in Figure 2. An initial mass loss of about $5 \%$ can be observed which can be attributed mainly to loss of moisture. The temperature at which the thermal degradation of Brazilwood was started was $210^{\circ} \mathrm{C}$ and was defined as the temperature at which there is a mass loss of $1 \%$ following the stabilization plateau that occurs after the initial moisture loss. For temperatures above $210^{\circ} \mathrm{C}$ two stages of thermal decomposition occur. These stages are due to the degradation of hemicellulose and to the thermal decomposition of cellulose, respectively. The temperatures at which the maximum degradation rate of these stages occurred were, respectively, $313^{\circ} \mathrm{C}$ and $380^{\circ} \mathrm{C}$, as indicated in the derivative curve (Figure $2 \mathrm{~b}$ ). It is important to emphasize that among the information obtained in the thermogravimetric test the ones related to the loss of humidity and the temperature of beginning of degradation are the most relevant for the use of wood, since these parameters can directly affect productive processes. For example, the temperature of the process of hot application of wood veneer coatings can not exceed the temperature at which wood degradation begins. In addition, several heat treatments have been used to increase wood properties (ESTEVES, 2009) and thus it is necessary to guarantee that the temperatures used in these treatments do not exceed the temperature of beginning of thermal degradation.

Revista Árvore, Viçosa-MG, v.40, n.6, p.1141-1147, 2016

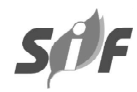



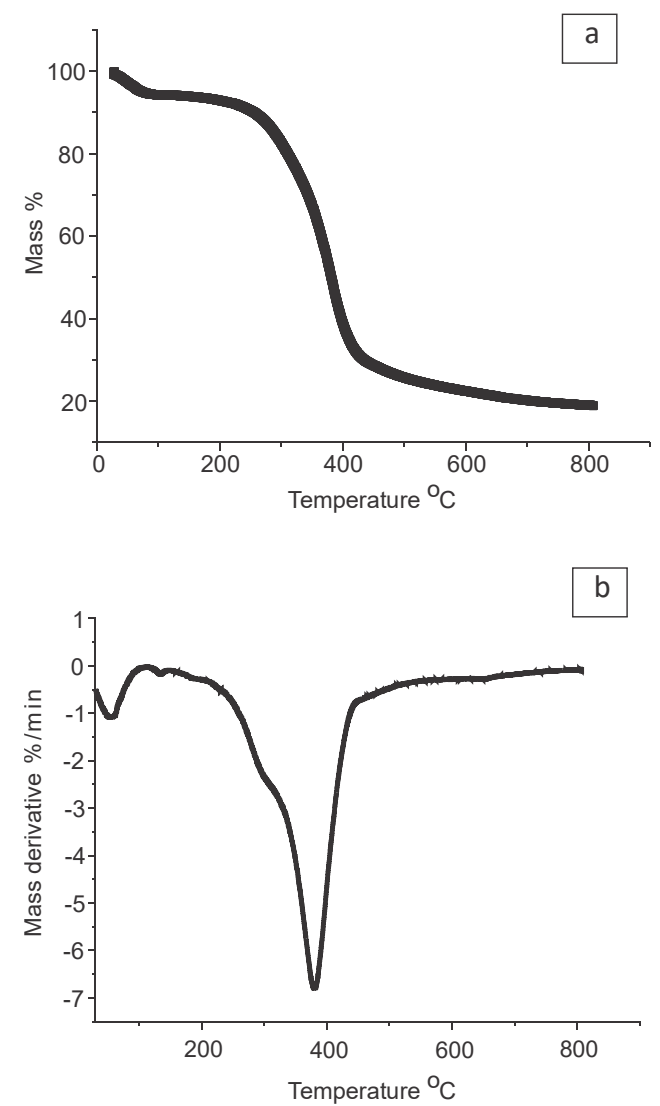

Figure 2 - Thermogravimetric analysis of Brazilwood: a) Mass loss vs. Temperature; b) DTG: Derivative of the mass loss vs. Temperature.

Figura 2-Análise termogravimétrica do pau-brasil: a) Perda de massa vs. Temperatura; b) DTG: Derivada da perda de massa vs. Temperatura.

The result of the X-ray diffraction analysis is shown in the diffractogram of Figure 3. From the peak intensities at $21.6^{\circ}$ referring to the diffraction of the $(002)$ plane of the native cellulose and the valley around $18^{\circ}$, referring to the signal of the amorphous halo, the crystallinity index of Brazilwood was calculated to be approximately $68 \%$.

In respect to the abrasion test (Figure 4), Brazilwood has a mean wear, evaluated by mass loss, of $2.73 \%$, and a wear rate $(W s)$ of $0.59 \pm 0.10 \mathrm{~cm}^{3} /$ N.m.

The water content absorbed by Brazilwood after 3 months of immersion was $23.8 \% \pm 2.1 \%$. Surface analysis after absorption showed minor changes, and the surface of the samples after immersion present a very similar appearance to the sample surfaces of

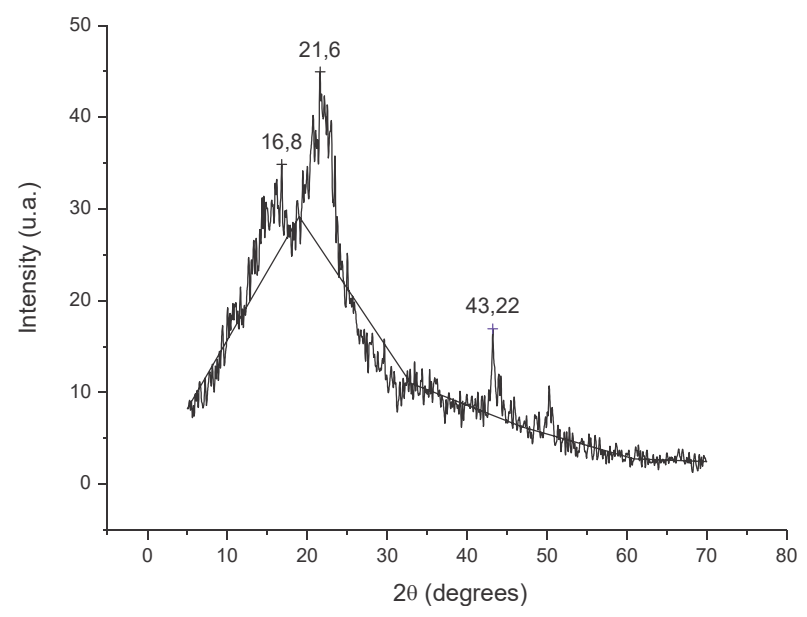

Figure 3 - X-rays difractogram of Brazilwood. Figura 3 - Difractograma do pau-brasil.

the original, as fabricated, samples prior to the abrasion test (Figure 5a).

The immersion of Brazilwood in sweat solution also did not cause significant changes in the surface of the samples, as shown in Figure $5 \mathrm{~b}$. In fact, there was no change in the $\mathrm{pH}$ of the sweat solution ( $\mathrm{pH}$ of 4.7) after immersion and, besides, the characteristic odor of the solution did not change, indicating that the contact with sweat does not affect Brazilwood.

For the biodeterioration test, the Petri dish chosen was the one with dilution $10^{1}$ in which measurements of colony counts were made on Brazilwood. The final result was $5.3 \times 10^{3} \mathrm{CFU} / \mathrm{mL}$.

\section{DISCUSSION}

The thermal behavior of Brazilwood obtained at thermogravimetric analysis is characteristic of lignocellulosic materials and agrees with results obtained for wood (CORRADINI et al., 2009) and wood-like materials, such as the pseudo-stem of peach palm (BACELLAR, 2010).

The value of the crystallinity index (68\%) obtained by X-ray diffraction is in accordance with the values reported for other wood or lignocellulosic materials, such as Pinus silvestre wood (65.1\%) (OLIVEIRA, 2011), sisal fibers (62\%) (RONG et al., 2001) or caroa fibers (65\%) (D'ALMEIDA et al., 2007). This crystallinity value is high and this result may be due to a higher cellulose content and/or better arrangement of the cellulose structure. It is important to note that the crystallinity 

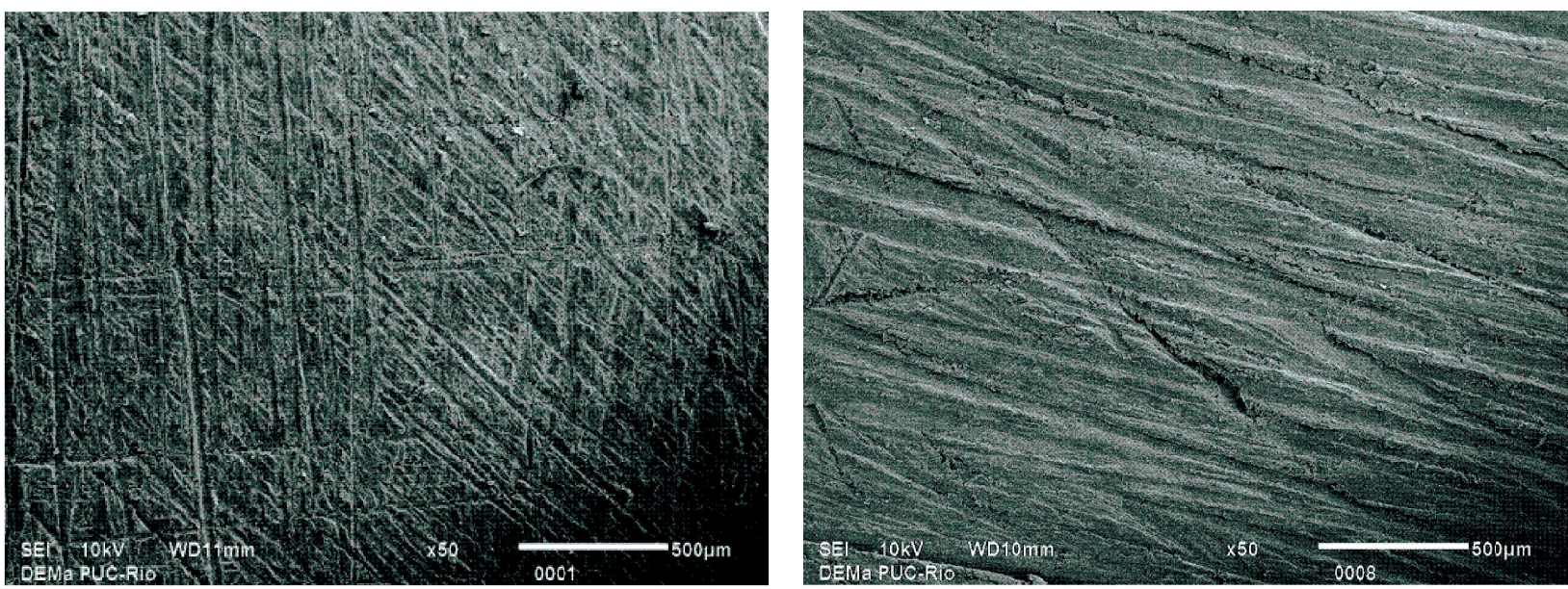

Figure 4 - Surface (a) before and (b) after the wear test. SEM $(50 \mathrm{x})$

Figura 4-Superfície (a) antes e (b) após o ensaio de abrasão. MEV (50x).
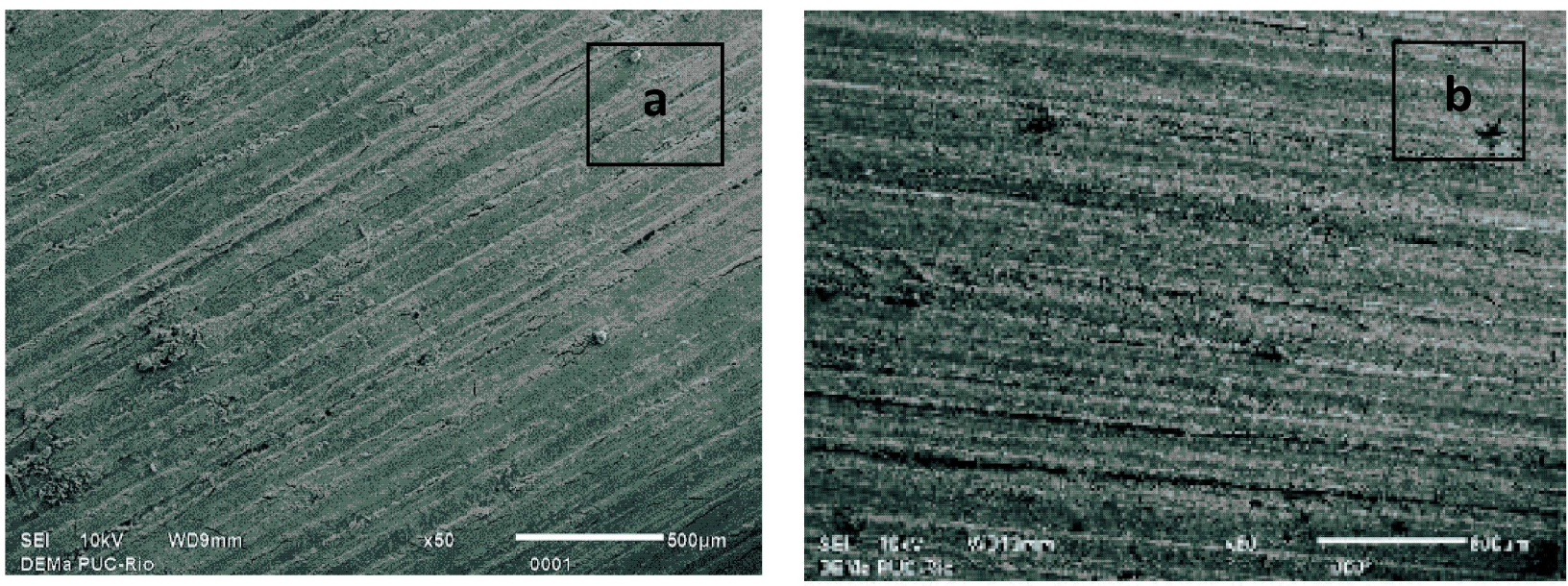

Figure 5 - Surface (a) after immersion in water and (b) after immersion in sweat solution. SEM (50 x). Figura 5 - Superfície (a) após imersão em água e (b) após imersão em solução de suor. MEV (50 x).

index is one of the structural parameters related to the long-term behavior of a semi-crystalline material when it is submitted to continuous mechanical stresses (MONTERO, 2012). Therefore, the creep phenomenon, observed in wood when it bows under a constant load - which may be the weight of the piece itself - is dependent on the relationship between the amount of the amorphous phase and the amount of the crystalline phase. Thus, the crystallinity index is an important parameter for the analysis of long-term mechanical behavior of wood structures.

The loss of mass, after the abrasion test, was very low $(2.73 \%)$, being lower than the values obtained in similar tests for species such as jatobá $(23.7 \%)$, sucupira
$(15.7 \%)$ and ipê $(12.6 \%)$, as well as bamboo (20.3\%) (OLIVEIRA, 2005). The low wear value corroborates the fact that the topographic characteristics observed on the surface of the Brazilwood before and after the abrasion test (Figure 4) showed no significant changes. The abrasion process seems to thin out only lightly some surface marks from the manufacturing process (Figures 4a vs. 4b). In fact, the values of the roughness parameters did not present significant variations before and after the abrasion. The arithmetic roughness (RA) values before and after mechanical wear were, respectively, $21.2 \mu \mathrm{m}$ and $26.4 \mu \mathrm{m}$. While for the quadratic roughness (RQ) the values before and after wear were $19.8 \mu \mathrm{m}$ and $24.8 \mu \mathrm{m}$, respectively.

\section{stif}

Revista Árvore, Viçosa-MG, v.40, n.6, p.1141-1147, 2016 
Regarding the absorption test, Brazilwood presented a higher value $(23.8 \% \pm 2.1 \%)$ than that obtained for the peach palm pseudo-stem, 12.5\% (BACELLAR, 2010), but much smaller than imbuia, 93.9\% (PINHEIRO, 2013). It is well known that swelling due to water absorption is a factor that can hinder the use of wood or wood derived materials. Thus, the value obtained here indicates that Brazilwood pieces present only an average performance in relation to this characteristic.

The biodeterioration results showed a comparatively low number $(5,300 \mathrm{CFU} / \mathrm{mL})$ when compared to the large number of CFU presented by imbuia, for example $(2,600,000$ CFU/mL)(PINHEIRO, 2013). This implies that Brazilwood presents low risk to facilitate the bacterial growth. The growth of bacteria in household utensils can be a source, among other factors, of allergies. Thus, the results indicate that furniture or other utensils obtained from Brazilwood will have low impact in this aspect. In addition, it is important to note that the biofilm formed on the surface of the Brazilwood samples had no adherence. A thin film was formed with little adherence to the substrate and was released without having to scrape it. The presence of bacterial growth in the plaques was also not observed. All these aspects indicate a high resistance of Brazilwood to biodeterioration.

\section{CONCLUSIONS}

The following conclusions were obtained from the results obtained:

- The temperature of the beginning of thermal degradation of Brazilwood, determined in the thermogravimetric test, is higher than the temperatures normally used in hot wood treatment processes, which indicates the feasibility of using these processes in Brazilwood;

- Brazil wood presented high crystallinity index when evaluated by X-ray diffraction, indicating that this wood must have good structural stability over time;

- Brazilwood presented high abrasion resistance, which contributes to the fact that there is no variation in its visual performance nor variation of its surface roughness after wear;

- Regarding deterioration tests (biodeterioration and interaction with sweat), Brazilwood presented an excellent performance, with low values related to fungal attacks, biofilm formation and/or any variation, including visual, caused by aggressive environments.

\section{ACKNOWLEDGEMENTS}

The authors acknowledge the financial support from CNPq.

\section{REFERENCES}

AGUIAR, F.F.A.; PINTO, M.M., TAVARES, A.R.; KANASHIRO, S. Maturação de frutos de Caesalpinia echinata Lam. Pau-Brasil. Revista Árvore, v.31, n.1, p.1-6, 2007.

AMERICAN PUBLISH HALTH ASSOCIATION APHA/AMERICAN WATER WORKS AWWA/ ASSOCIATION/WEF. Water Environment Federation. Standard Methods for the Examination of Water and Wastewater. 21.ed. Washington: APHA. 2005.

BACELLAR, R.S. Caracterização microestrutural e mecânica de resíduos da agroindústria. Dissertação (Engenharia de Materiais) - Pontifícia Universidade Católica do Rio de Janeiro, 2010.

CORRADINI, E.; ROSA, M.F.; MACEDO, B.P.; PALADIN P.D.; MATTOSO, L.H.C. Composição química, propriedades mecânicas e térmicas da fibra de frutos de cultivares de coco verde.

Revista Brasileira de Fruticultura, v. 31 , n.3, p.837-846, 2009.

D'ALMEIDA, J.R.M.; D'ALMEIDA, A.L.F.S.; CARVALHO, L.H. Mechanical, morphological and structural characteristics of caroá (Neoglaziovia variegata) fibers. Polymers \& Polymer Composites, v.16, p.577-583, 2007.

ESTEVES, B.M.; PEREIRA, H.M. Wood modification by heat treatment: a review. BioResources, v.4, p.370-404, 2009.

FRIEDRICH, K. (Ed.) Friction and wear of polymer composites. Amsterdam: Elsevier, 1986.

LONGHI, E.L. Pau-Brasil e outras espécies nativas empregadas na confecção de arcos para instrumentos de corda: um estudo comparativo. Dissertação (Mestrado em Botânica) - Universidade de São Paulo, São Paulo, 2005. 
LORENZI, H. Árvores brasileiras. Manual de identificação e cultivo de plantas arbóreas nativas do Brasil. 5.ed. Nova Odessa. Instituto Plantarum de Estudos da Flora, 2008. 382p.

\section{MENEZES, R.P. Medidas em escala} nanométrica de propriedades mecânicas e ópticas em superfícies. Tese (Doutorado em Física) - Centro Brasileiro de Pesquisas Físicas, Rio de Janeiro, 1998.

MONTERO, C.; CLAIR, B.; ALMÉRAS, T.; VAN DER LEE, A.; GRIL, J. Relationship between wood elastic strain under bending and cellulose crystal strain. Composites Science and Technology, V.72, p.175-181, 2012.

MORESI, C.M.D. Aspectos técnicos na pintura de Manoel da Costa Ataíde. In: CAMPOS, A. A. (Org.) Manoel da Costa Ataíde: aspectos históricos, estilísticos, iconográficos e técnicos. Belo Horizonte: C/Arte, 2005. p. 111-143.

OLIVEIRA, A.K.F. Caracterização físicomecânicas de laminado colado de bambu. Dissertação (Mestrado em
Engenharia) - Universidade Federal de Campina Grande, Campina Grande, 2005.

OLIVEIRA, A.K.F. Estudo da viabilidade técnica de utilização do compósito poliuretano de resina de mamona e fibra de ubuçu na fabricação de pisos e revestimentos. Tese (Doutorado em Engenharia de Materiais) - Pontifícia Universidade Católica do Rio de Janeiro, Rio de Janeiro, 2011.

PINHEIRO, A.P.P. Análises

microestruturais de espécies de madeira e estudo da viabilidade de utilização em design de jóias.

Dissertação (Mestrado em Engenharia de Materiais) - Pontifícia Universidade Católica do Rio de Janeiro, Rio de Janeiro, 2013.

RONG, M.Z.; ZHANG, M.Q.; LIU, Y.; YANG, G.C.; ZENG, H.M. The effect of fiber treatment on the mechanical properties of unidirectional sisalreinforced epoxy composites. Composites Science and Technology. V.61, p. 1437-1447, 2001. 